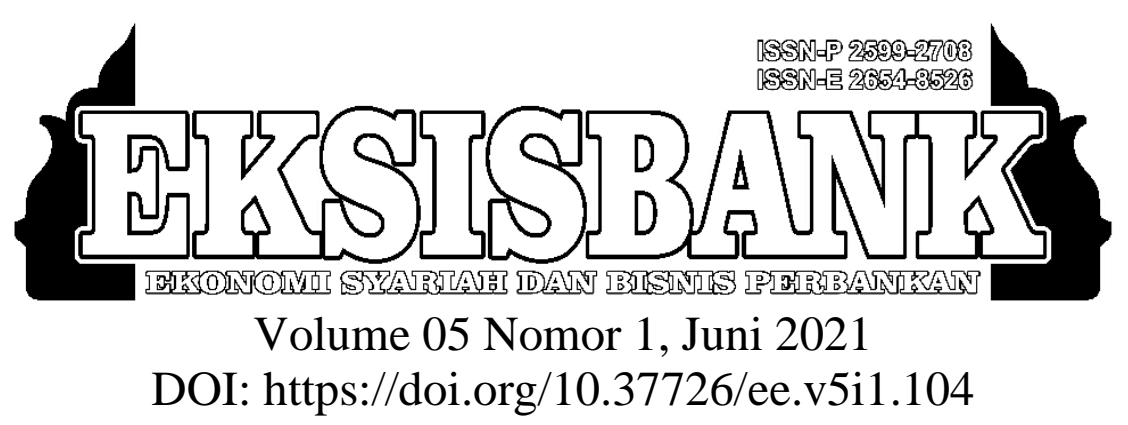

\title{
Praktik Sewa Menyewa Rental Mobil Dump Truck Ditinjau Dari Ekonomi Syari'ah Di CV. Tunggal Perkasa Purwakarta
}

\author{
Abdul Rouf ${ }^{1}$, Ahmad Saepudin $^{2}$, Siti Rohmat ${ }^{3}$ \\ ${ }^{1,3}$ Sekolah Tinggi Ilmu Ekonomi Syariah (STIES) Indonesia Purwakarta \\ ${ }^{2}$ Universitas Islam Negeri Sunan Gunung Djati Bandung \\ 1rouf22592@gmail.com \\ 2ahmadsaepudin@sties-purwakarta.ac.id \\ ${ }^{3}$ sitirohmat@sties-purwakarta.ac.id
}

\begin{abstract}
ABSTRAK
Sebuah perkembangan usaha binis sewa menyewa, seperti sewa menyewa mobil di CV Tunggal Perkasa yang bergerak pada jasa sewa menyewa mobil damp truck bidang ekspedisi, dalam sewa menyewa ini terjadi sebuah perjanjian dimana sewa menyewa ini menimbulkan hak dan kewajiban bagi para kedua pihak. Dalam Islam sewa menyewa diistilahkan dengan alijarah yaitu akad pemindahan hak guna atas barang atau jasa, melalui pembayaran upah sewa, tanpa diikuti dengan pemindahan kepemilikan (ownership/milkiyah) atas barang itu sendiri. Tujuan dari penelitian ini adalah untuk mengetahui praktik sewa menyewa mobil jasa angkut di CV. Tunggal Perkasa, dan untuk mengetahui tinjauan ekonomi syari'ah dalam sewa menyewa di CV. Tunggal Perkasa. Jenis penelitian yang digunakan adalah penelitian lapangan (field research), adapun pendekatan yang digunakan dalam penelitian ini adalah pendekatan deskriptif-kualitatif. Mekanisme yang dilakukan dalam praktik sewa menyewa mobil dump truck yaitu melakukan sebuah kontrak perjanjian dengan syarat dan ketentuan yang sudah ditetapkan, dan sistem sewa menyewa yang diterapkan pada kedua belah pihak tersebut yaitu terikat. Jika dilihat dari segi akad, rukun dan syarat sewa menyewa ditinjau menurut Fatwa Dewan Syariah Nasional-Majelis Ulama Indonesia NO: 112/DSN-MUI/IX/2017 akad sewa menyewa yang dilakukan oleh kedua belah pihak ini tidak sesuai dengan Fiqih Ijarah.
\end{abstract}

Kata kunci- CV Tunggal Perkasa, Ijarah, Sewa Menyewa, dan Mekanisme.

\section{ABSTRACT}

A development of the leasing business, such as renting a car at CV Tunggal Perkasa which is engaged in car rental services in the field of expeditions, in this lease there is an agreement where this lease creates rights and obligations for both parties. In Islam, leasing is termed al-

EKSISBANK (Ekonomi Syariah dan Bisnis Perbankan), Volume 5, Nomor 1, Juni 2021 
ijarah, which is a contract for the transfer of usufructuary rights over goods or services, through payment of rental wages, without being followed by a transfer of ownership (milkiyah) of the goods themselves. The purpose of this study was to determine the practice of renting a car rental service at CV. Tunggal Perkasa, and to find out an overview of the sharia economy in leasing at CV. Mighty Single. The type of research used is field research, while the approach used in this research is a descriptive-qualitative approach. The mechanism used in the practice of renting a dump truck is to enter into a contract agreement with predetermined terms and conditions, and the rental system applied to both parties is bound. When viewed from the perspective of the contract, the pillars and terms of the lease are reviewed according to the Fatwa of the National Sharia Council-Indonesian Ulema Council NO: 112/DSNMUI/IX/2017. The lease agreement made by both parties is not in accordance with Fiqh Ijarah. Keywords - CV Perkasa Perkasa, Ijarah, Leasing, and Mechanism.

\section{PENDAHULUAN}

Bisnis tidak harus tentang jual beli, karena pada saat ini bisnis dapat juga tentang sewa menyewa (rental). Perkembangan bisnis dewasa ini, mengalami perubahan ke arah halhal yang praktis, misalnya jasa rental mobil, artinya menggunakan mobil yang disewakan oleh pemilik mobil (pihak yang menyewakan) kepada penyewa (pihak yang menyewa mobil). Kebutuhan kendaraan roda empat di Indonesia semakin meningkat setiap tahunnya yang mengakibatkan meningkatnya jumlah produksi mobil dan harga mobil (Tanuwijaya 2012).

Sewa menyewa merupakan perjanjian konsensual, artinya perjanjian tersebut sah dan mengikat pada detik tercapainya sepakat mengenai unsur-unsur pokoknya, yaitu barang dan harga (Subekti and Tjitrosudibio 2014). Dalam Islam sewa menyewa diistilahkan dengan al-ijarah. Al-ijarah adalah akad pemindahan hak guna atas barang atau jasa, melalui pembayaran upah sewa, tanpa diikuti dengan pemindahan kepemilikan (ownership /milkiyah) atas barang itu sendiri (Antonio 2001).

Berdasarkan ketentuan landasan teori dalam Islam bahwa sewa menyewa merupakan salah satu bentuk kegiatan muamalah dalam memenuhi kebutuhan hidup manusia, dalam konsep ekonomi syariah sewa menyewa disebut dengan (al-ijarah), yang mempunyai rukun dan syarat yang menjadi ketentuan sah nya akad ijarah tersebut. Dalam usaha bisnis, konsep amanah merupakan niat dan itikad yang perlu diperhatikan, sebab Islam telah mengharamkan setiap hubungan bisnis atau usaha yang mengandung kezaliman dan mewajibkan terpenuhinya keadilan yang teraplikasikan dalam hubungan usaha dan kontrak-kontrak serta perjanjian bisnis.

Seperti halnya pada CV Tunggal Perkasa yang berlokasi di kabupaten Purwakarta adalah sebuah bisnis yang bergerak di bidang ekspedisi atau sewa menyewa mobil angkutan barang. Dikarenakan terbatasnya jumlah unit mobil truk yang dimiliki oleh $\mathrm{CV}$ dan Banyaknya permintaan dari sebuah perusahaan untuk melakukan jasa ekspedisi, maka di CV Tunggal Perkasa terkadang terkadang kekurangan unit mobil untuk melakukan permintaan tersebut (Nurjaman 2019).

CV Tunggal Perkasa mempunyai jumlah unit mobil yang di sewakan kurang lebih 30 unit, dengan rincian sebagai berikut; pick up 2 unit, kol diesel 14 unit, fuso engkel 3 unit, fuso tronton 4 unit, long sasis 5 unit, dump truck 7 unit, fuso dump truck 4 unit, dengan kapasitsas disetiap mobil berbeda-beda. 
Hal ini menjadikan perbuatan sewa menyewa itu melahirkan perjanjian sewa menyewa yang menimbulkan adanya hak dan kewajiban dari para pihak yang melaksanakan sewa menyewa (Subekti and Tjitrosudibio 2014). Melihat hal tersebut dalam menjalankan sebuah usaha jasa sewa mobil terdapat berbagai masalah yang timbul dalam sebuah akad perjanjian ataupun dalam hal lain yang dilakukan penelitian khususnya mengenai pelaksanaan perjanjian yang terjalin antara penyewa dan perusahaan rental mobil, adapun maksud dan tujuan dari penelitian ini adalah untuk mengetahui praktik sewa menyewa mobil jasa angkut di CV. Tunggal Perkasa, dan untuk mengetahui tinjauan ekonomi syari'ah dalam sewa menyewa di CV. Tunggal Perkasa.

\section{A. Pengertian Ijarah}

Menurut Idris Ahmad dalam bukunya yang berjudul Fiqh Syafi'i, berpendapat bahwa ijarah berarti upah-mengupah. Hal ini terlihat ketika beliau menerangkan tentang rukun dan sayarat upah-mengupah, yaitu mu'jir dan musta 'jir (yang memberi upah dan yang menrima upah) (Suhendi 2014). Dalam kitab undang-undang hukum perdata (KUHPER) pasal 1548 dijelaskan bahwa sewa menyewa ialah suatu perjanjian, dengan mana pihak yang satu mengikatkan dirinya untuk memberikan kepada pihak yang lainnya kenikmatan dari suatu barang, selama suatu waktu tertentu dan dengan pembayaran sesuatu harga, yang oleh pihak tersebut belakangan itu disanggupi pembayaranya (Subekti and Tjitrosudibio 2014).

Menurut syara'sewa memyewa (ijarah) adalah transaksi sewa menyewa atas suatu barang dan atau upah mengupah atas suatu jasa dalam waktu tertentu melalui pembayaran sewa atau imbal jasa. Ijarah salah satu akad mu'awadhat, yaitu transaksi yamg betujuan untuk mendapatkan keuntungan atau manfaat material (Sariningsih, Bahri, and Nurbaeti 2020). Di samping itu, akad ijarah termasuk akad bernama (al-uqud al-musamma), yaitu akad yang batasan-batasanya ditentukan dalam AlQuran dan/atau sunah Nabi Muhammad Saw. Sedangkan kebalikannya adalah akad tidak bernama (al-uqud ghair al-musamma), yaitu akad-akad baru yang kriteria dan ketentuanya tidak ditentukan secara langsung dalam AlQuran dan/atau subah Nabi Muhammad saw.

Bedasarkan definisi-definisi di atas, kiranya dapat dipahami bahwa ijarah adalah menukar sesuatu dengan adanya imbalannya, diterjemahkan dalam bahasa Indonesia berarti sewa-menyewa dan upah-mengupah, sewa-menyewa adalah "Menjual manfaat dan upah mengupah adalah menjual tenaga atau kekuatan" (Suhendi 2016). Dalam tataran implementasinya, ijarah ini dapat dipilah kepada dua bagian besar, yaitu ijarah bi alquwwah dan ijarah bi al-manfaah. Ijarah itu dikatakan sebagai ijarah bi al-quwwah apabila yang disewakan itu berupa jasa atau tenaga manusia. Sedangkan ijarah itu dikatakan sebagai ijarah bi al-manfaah apabila yang diswakan itu berupa barang. Namun kedua ijarah tersebut memiliki prinsip-prinsip yang sama, yakni menyewa atau menyewakan sesuatu (Janwari 2015).

\section{B. Dasar Hukum Sewa menyewa}

Dalam al Quran Allah swt berfirman pada surat:

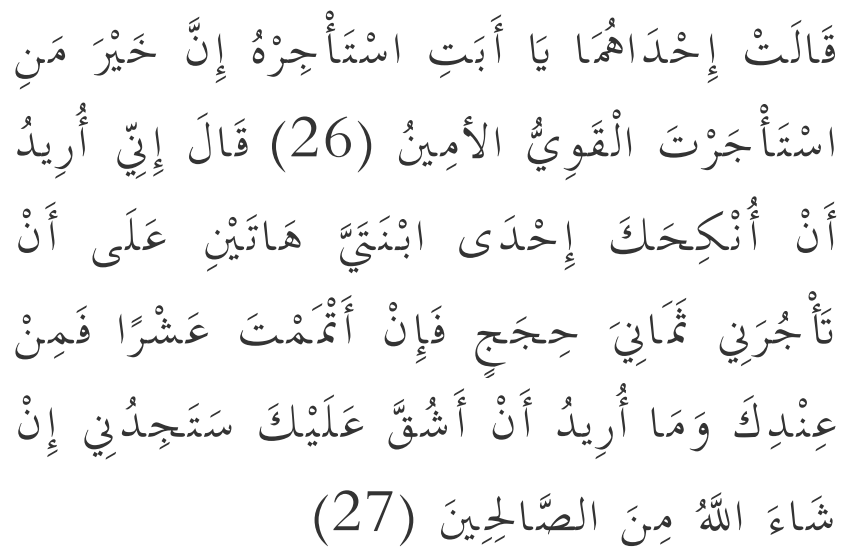


"Salah seorang dari kedua wanita itu berkata: "Ya bapakku ambillah ia sebagai orang yang bekerja (pada kita), karena sesungguhnya orang yang paling baik yang kamu ambil untuk bekerja (pada kita) ialah orang yang kuat lagi dapat dipercaya". Berkatalah dia (Syu'aib): "Sesungguhnya aku bermaksud menikahkan kamu dengan salah seorang dari kedua anakku ini, atas dasar bahwa kamu bekerja denganku delapan tahun dan jika kamu cukupkan sepuluh tahun maka itu adalah (suatu kebaikan) dari kamu, maka aku tidak hendak memberati kamu. Dan kamu Insya Allah akan mendapatiku termasuk orang-orang yang baik". (QS. AlQashash/26-27).

Hadits Bukhari

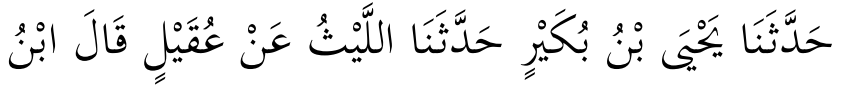

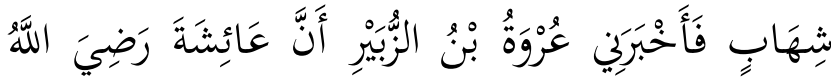

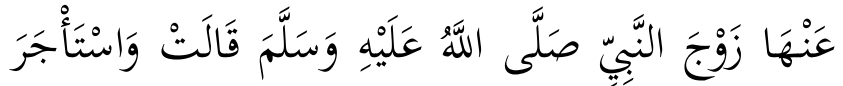

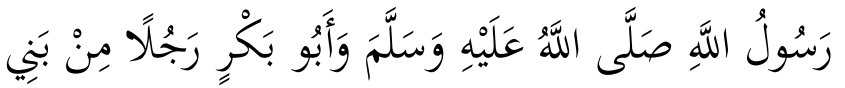

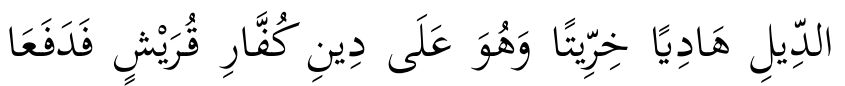

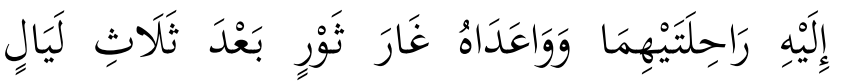

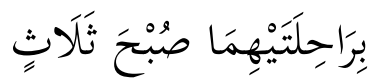

Telah menceritakan kepada kami Yahya bin Bukair telah menceritakan kepada kami Al Laits dari 'Uqail berkata, Ibnu Syihab telah mengabarkan kepada saya 'Urwah bin Az Zubair bahwa 'Aisyah radliallahu 'anha isteri Nabi shallallahu 'alaihi wasallam berkata: "Rasulullah shallallahu 'alaihi wasallam dan Abu Bakar menyewa seorang dari suku AdDil sebagai petunjuk jalan yang dipercaya yang orang itu masih memeluk agama kafir Quraisy. Maka keduanya mempercayakan kepadanya perjalanan keduanya lalu keduanya meminta kepadanya untuk singgah di gua Tsur setelah perjalanan tiga malam." (H.R. al-Bukhari) (Sukasari n.d.).

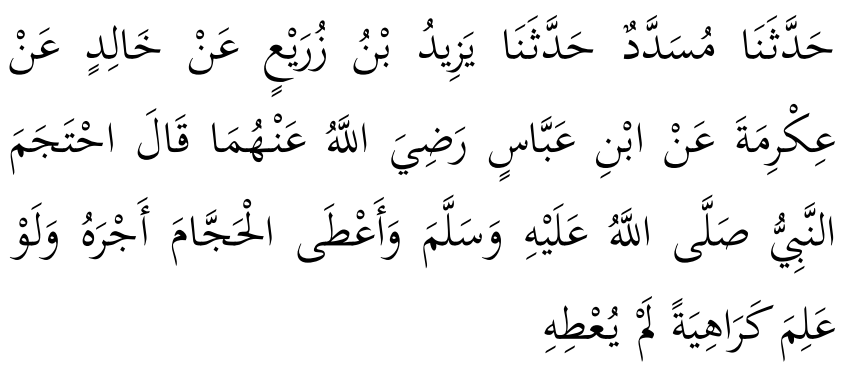

Telah menceritakan kepada kami Musaddad telah menceritakan kepada kami Yazid bin Zurai' dari Khalid dari 'Ikrimah dari Ibnu 'Abbas radliallahu 'anhuma berkata; "Nabi shallallahu 'alaihi wasallam berbekam dan memperi upah tukang bekamnya. Seandainya Beliau mengetahui bahwa berbekam makruh tentu Beliau tidak memberi upah”. (H.R. alBukhari) (Ash-Shiddieqy 2002).

\section{Rukun dan Syarat}

Menurut ulama Hanafiyah, rukun ijarah adalah ijab dan qabul, antara lain dengan menggunakan kalimat: al-ijarah, al-istijar, al-iktira', dan al-ikra. Adapun menurut jumhur ulama, rukun ijarah ada (4) empat, yaitu (Syafei 2011):

1.Aqid, (orang yang akad) yaitu mu'jir dan musta'jir.

2. Sighat (ijab dan qabul)

3. Ujrah (upah)

4. Manfaat, baik manfaat dari suatu barang yang disewa atau jasa dan tenaga dari orang yang bekerja.

Syarat ijarah terdiri empat macam, sebagaimana syarat dalam jual beli, yaitu syarat al-inqad (terjadinya akad), syarat annafadz (syarat pelaksanaan akad), syarat sah dan syarat lazim. sebagai berikut:

a. Syarat Terjadinya Akad : Ulama Hanabilah dan Syafi'iyah mensyaratkan orang yang akad harus mukallaf, yaitu baligh dan berakal, sedangkan anak mumayyiz belum dapat dikategorikan ahli akad (Syafei 2006).

b.Syarat An-Nafadz (Syarat Pelaksanaan Akad) : Agar ijarah terlaksana, barang

EKSISBANK (Ekonomi Syariah dan Bisnis Perbankan), Volume 5, Nomor 1, Juni 2021 
harus dimiliki oleh 'aqid atau ia memiliki kekuasaan penuh untuk akad (ahliah).

c. Syarat Sah Ijarah : Kerelaan kedua pihak pelaku akad, Manfaat barang atau jasa yang disewa harus jelas, Hendaklah keadaan manfaat jasa yang disewakan itu diketahui, Hendaklah status upah diketahui, Kondisi manfaat jasa bisa diambil secara penuh, Hendaklah manfaat yang disewakan adalah milik sah penjual jasa atau diizinkan olehnya, Hendaklah masa ijarah itu diketahui.

d. Syarat Kelaziman : Ma'qud alaih ( barang sewaan) terhindar dari cacat, Tidak ada udzur yang membatalkanya.

\section{Jenis-jenis Ijarah}

Dilihat dari Obyeknya ijarah dapat dibagi menjadi dua macam; yaitu ijarah yang bersifat manfaat dan yang bersifat pekerjaan.

1. Ijarah yang bersifat manfaat (Hasan 2003)

Akad sewa manfaat yang bersinggungan langsung dengan bendanya, seperti menyewakan tanah pekarangan, hewan pengangkut yang telah ditentukan, dan mempekerjakan orang tertentu untuk melakukan pekerjaan tertentu (Zuhaili 2010).

2. Ijarah Yang Bersifat Pekerjaan

Ijarah yang bersifat pekerjaan (Al-Ijarah ala al- a'mal); yaitu dengan cara mempekerjakan seseorang untuk melakukan sesuatu. Mu'jir adalah orang yang mempunyai keahlian, tenaga, jasa dan lain-lain. Musta 'jir adalah pihak yang membutuhkan keahlian, tenaga atau jasa tersebut dihargai dengan imbalan tertentu. Mu'jir mendapatkan upah (ujrah) atas tenaga yang ia keluarkan untuk musta'jir dan Musta'jir mendapatkan tenaga atau jasa dari mu'jir (Afandi 2010).

\section{E. Berakhirnya Akad Ijarah}

Menurut Sayyid Sabiq, akad al-ijarah dapat menjadi batal dan berakhir apabila ada hal-hal sebagai berikut:

1. Terjadinya cacat pada barang sewaan ketika ditangan penyewa.

2. Rusaknya barang yang disewakan, seperti ambruknya rumah runtuhnya bangunan gedung.

3. Rusaknya barang yang diupahkan, seperti bahan baju yang diupahkan untuk dijahit.

4. Telah terpenuhinya manfaat yang diakadkan sesuai dengan masa yang telah ditentukan dan selesainya pekerjaan.

Menurut Hanafiyah salah satu pihak dari yang berakad boleh membatalkan akad alijarah jika ada kejadian-kejadian yang luar biasa, seperti terbakarnya gedung, tercurinya barang-barang dagangan, dan kehabisan modal (Ghazaly, Ihsan, and Shidiq 2010).

\section{TINJAUAN PUSTAKA}

Penelitian tentang Praktik Sewa Menyewa Rental Mobil Dump Truck Ditinjau Dari Ekonomi Syari'ah ternyata belum terlalu banyak dilakukan penelitian kebanyakan penelitian tentang Dum Truk diluar kajian ekonomi Syariah, adapun penelitian yang berhubungan dengan Dump Truck adalah sebagai beriku:

A. Optimasi Penyewaan Dump Truck Pada Proyek X Di Wilayah Jakarta Dengan Metode Linear Programming

Studi ini menangani masalah pengoptimalan penyewaan Dump Truck untuk meminimalkan biaya sewa Dump Truck. Metode Linear Programming merupakan metode yang digunakan dalam mengoptimalkan penyewaan Dump Truck. Metode Linear Programming terdiri dari decision variabel, objective function, dan constraint. Penelitian menggunakan 10 perusahaan Dump Truck yang disewa untuk

EKSISBANK (Ekonomi Syariah dan Bisnis Perbankan), Volume 5, Nomor 1, Juni 2021 
mengangkut tanah dengan 2 tipe kapasitas yang berbeda. Data tersebut diolah dengan menggunakan program LINGO untuk menentukan banyak Dump Truck yang digunakan dari perusahaan-perusahaan dan didapat harga termurah yang perlu dikeluarkan adalah $\mathrm{Rp}$ 3.183.989.000,-. Program LINGO ini membuktikan bahwa biaya yang diperoleh lebih efisien dengan mrnggunakan metode Linear Programming dibandingkan dengan cara memesan secara aktual di lapangan (Handokoe and Santoso 2018).

Perbedaan dengan penelitian yang dilakukan peneliti saat ini adalah Lokasi Penelitian yang berbeda, berbeda kajian terkait objek penelitian dalam hal ini Dump Truck, Peneliti terdahulu menkaji Dump Truck dalam metode kajian Linear Programming sedang Peneliti saat ini mengkaji Dump Truck dalam kajian ekonomi Syariah.

B. Analisis Komparatif Antara Membeli Dan Menyewa Dump Truck PT. Global Daya Manunggal Di Sangatta

Analisis komparatif antara membeli dan menyewa dump truck pada PT. Global Daya Manunggal di Sangatta ini bertujuan untuk membandingkan alternatif mana yang lebih menguntungkan antara membeli dump truck secara kredit bank atau menyewa dump truck pada PT. Global Daya Manunggal. Alat analisis yang digunakan dalam penelitian ini, yaitu : Metode Net Present Value, Berdasarkan hasil penelitian diketahui bahwa dalam pemilihan alternatif membeli atau menyewa dump truck mayoritas lebih menguntungkan untuk membeli melalui kredit bank dibandingkan dengan menyewa dump truck melalui sewa guna usaha dengan selisih nilai total PV arus kas keluar sebesar Rp 12.917.911 dimana hasil tersebut merupakan selisih dari selisih nilai tunai arus kas keluar antara alternatif kredit bank sebesar Rp 507.125.911 dan alternatif menyewa dengan sewa guna usaha sebesar Rp 494.208.000 Dengan demikian, membeli merupakan pilihan lebih baik karena total secara keseluruhan biaya yang dikeluarkan lebih rendah dibandingkan menyewa (Barbara 2015).

Perbedaan Peneliti terdahulu dengan Peneliti saat ini adalah lokasi penelitian yang berbeda, kajian objek penelitian (Dump Truck) dalam kajian studi komparasi atau perbandingan antara membeli dan menyewa, sedang peneliti saat ini kajian sewa menyewa Dump Truck dalam kajian ekonomi Syariah.

C. Perbandingan Investasi Dengan Sewa Alat Berat Pada Proyek Pembangunan Hotel Ibis Raden Saleh Jakarta (Marcell and Sulistio 2021)

Penelitian dilakukan untuk mempertimbangkan pemilihan antara investasi atau sewa alat berat menguntungkan atau tidak menguntungkan untuk dilakukan sebagai pengambilan keputusan. Metode pengumpulan data yang digunakan pada penelitian ini adalah metode wawancara sebagai data primer dan dokumentasi sebagai data sekunder. Metode analisis data menggunakan studi analisis finansial yaitu NPV (Net Present Value), IRR (Internal Rate of Return), BCR (Benefit Cost Ratio), dan PBP (Payback Period). Berdasarkan hasil perhitungan didapatkan nilai NPV untuk investasi sebesar - Rp 12,216,701,317.38 (NPV < 0) dan nilai NPV untuk sewa sebesar Rp 16,083,224,759.60 (NPV > 0). Besaran nilai IRR untuk investasi sebesar $0 \%$ (IRR < MARR) dan nilai IRR untuk sewa sebesar 22.28\%. (IRR > MARR). Besaran nilai BCR untuk investasi sebesar $0.62(\mathrm{BCR}<1)$ dan besaran nilai BCR untuk sewa sebesar 4.81 (BCR > 1). Besaran nilai PBP untuk investasi belum dapat dinilai (PBP > umur proyek) dan 
besaran nilai PBP untuk sewa adalah 5.0596 bulan (PBP < umur proyek). Berdasarkan penelitian, dapat disimpulkan kegiatan yang menguntungkan dilakukan adalah sewa alat berat.

Perbedaan Peneliti terdahulu dengan Peneliti saat ini adalah lokasi penelitian yang berbeda, kajian objek penelitian (Dump Truck) dalam kajian studi komparasi atau perbandingan antara investasi dengan sewa alat berat pada proyek pembangunan Hotel Ibis Raden Saleh Jakarta, sedang peneliti saat ini kajian sewa menyewa Dump Truck dalam kajian ekonomi Syariah.

\section{METODOLOGI PENELITIAN}

Jenis penelitian ini adalah penelitian lapangan (field research) yaitu penelitian yang objeknya mengenai gejala-gejala atau peristiwa-peristiwa yang terjadi pada kelompok masyarakat. Sehingga penelitian ini juga bisa disebut penelitian kasus atau study kasus (case study) dengan pendekatan deskriptif kualitatif (Arikunto 2013).

Penelitian kualitatif yaitu penelitian yang menghasilkan prosedur analisis yang tidak menggunakan prosedur analisis statistik atau cara kuantifikasi lainnya. Jelas bahwa pengertian ini mempertentangkan penelitian kualitatif dengan penelitian yang bernuansa kuantitatif yaitu dengan menonjolkan bahwa usaha kuantifikasi apapun tidak perlu digunakan pada penelitian kualitatif. Jenis penelitian ini adalah penelitian lapangan (field research), data diperoleh di lapangan, artinya adalah penelitian langsung guna memperoleh data dari fakta-fakta yang terjadi pada pihak CV Tunggl Perkasa.

Teknik pengumpulan data merupakan cara yang dilakukan peneliti untuk mengungkap atau menjaring informasi dari responden sesuai lingkup penelitian. Berikut ini ada beberapa teknik pengumpulan data:

A. Wawancara
Penelitian ini menggunakan jenis wawancara terbuka dan terstruktur, arti dari wawancara terbuka itu sendiri adalah wawancara yang para subjeknya tahu bahwa mereka sedang diwawancarai dan mengetahui pula apa maksud dan tujuan wawancara itu (Moleong 2017). Wawancara terstruktur adalah wawancara yang pewawancaranya menetapkan sendiri masalah da pertanyaan-pertanyaan yang akan diajukan (Moleong 2017). Penelitian ini dilakukan secara terstruktur dan terbuka, dimana yang diwawancarai baik pihak karyawan dan konsumen telah mengetahui apa maksud dan tujuan pewawancara dan susunan pertanyaan telah disiapkan sesuai apa yang akan ditanyakan, apa yang ingin didapatkan untuk dijadikan sumber data. Wawancara dilakukan kepada pihak yang terlibat, yaitu staff dan pemilik CV Tunggal Perkas. Waktu dan tempat dilakukan dengan wawancara ini adalah secara langsung.

B. Observasi

Observasi yang dilakukan dalam penelitian ini adalah jenis observasi pasif (passive participation) adalah jenis obervasi yang dalam hal ini peneliti datang di tempat kegiatan orang yang diamati, tetapi tidak ikut terlibat dalam kegiatan tersebut (Sugiyono 2017). Maka, dalam penelitian ini peneliti hanya mengamati dan observasi secara intensif terhadap objek yang diteliti yaitu mekanisme sewamenyewa dump truck di CV Tunggal Perkasa Purwakarta. Melakukan pencatatan secara sistemik terhadap halhal yang berkaitan dengan penelitian tersebut. Maka, dalam penelitian ini peneliti hanya mengamati dan observasi secara langsung dengan cara datang dan mengamati mekanisme sewa menyewa dump truck. 


\section{Dokumentasi}

Dokumentasi merupakan salah satu bukti bahwa penulis benar melakukan penelitian. Dokumentasi penulis berupa foto, dan hasil dari wawancara. Dokumen yang didapat dari sini adalah dokumen data laporan dokumen, dokumentasi wawancara, dokumentasi SOP mekanisme sewa menyewa (Mahmud 2011). Dokumen mengenai daftar pertanyaan serta isi dari hasil wawancara.

Sumber data adalah subjek dari mana asal data penelitian itu diperoleh. Dalam melakukan penelitian ini data-data yang diperlukan diperoleh dari dua sumber yaitu:

1. Data Primer

Data primer adalah data yang dikumpulkan dan diolah sendiri oleh suatu organisasi atau perorangan langsung dari objeknya. Pengumpulan data tersebut dilakukan secara khusus untuk mengatasi masalah riset yang sedang diteliti. Sumber primer dalam penelitian ini di dapat dari hasil wawancara yang dilakukan terhadap pihak CV Tunggal Perkasa dan juga masyarakat.

2. Data Sekunder

Data sekunder adalah data yang diperoleh dalam bentuk yang sudah jadi, sudah dikumpulkan dan diolah oleh pihak lain, biasanya sudah dalam bentuk publikasi. Data semacam ini sudah dikumpulkan pihak lain untuk tujuan tertentu yang bukan untuk keperluan riset yang sedang dilakukan peneliti saat ini secara spesifik (Hendryadi 2015). Sumber sekunder penelitian ini diperoleh dari data atau arsip buku-buku referensi, dan situs website.

Analisis data adalah proses mencari dan menyusun secara sistematis data yang diperoleh dari hasil wawancara, catatan lapangan, dan bahan-bahan lain, sehingga dapat mudah dipahami, dan temuannya dapat diinformasikan kepada orang lain (Sugiyono
2017). Analisis data dalam penelitian kualitatif dilakukan sejak sebelum memasuki lapangan, selama di lapangan dan setelah selesai di lapangan. Dalam hal ini Nasution menyatakan:

"Analisis telah dimulai sejak merumuskan dan menjelaskan masalah, sebelum terjun kelapangan dan berlangsung terus sampai penulisan hasil penelitian. Analisis data menjadi pegangan bagi penelitian selanjutnya sampai jika mungkin, teori yang grounded. Namun dalam penelitian kualitatif, analisis data lebih difokuskan selama proses di lapangan bersama dengan pengumpulan data. In fact, data analysis in qualitative research is an on going activity tha occurs throughout the investigative process rather than after process. Dalam kenyataannya, analisis data kualitatif berlangsung selama proses pengumpulan data dari pada setelah selesai pengumpulan data."

Miles dan Huberman mengemukakan bahwa aktivitas dalam analisis data kualitatif dilakukan secara interaktif dan berlangsung secara terus sampai tuntas, sehingga datanya sudah jenuh. Aktivitas dalam analisis data, yaitu: data reduction, data display, dan conclusion drawing/verification.

Keabsahan data dalam penelitian ini ditentukan dengan menggunakan kriteria kredibilitas. Untuk mendapatkan data yang relevan, maka peneliti melakukan pengecekan keabsahan data hasil penelitian dengancara:

a) Perpanjangan Pengamatan

Dalam penelitian ini peneliti melakukan perpanjangan pengamatan, dengan kembali lagi ke lapangan untuk memastikan apakah data yang telah penulis peroleh sudah benar atau masih ada yang salah.

b) Ketekunan Pengamatan

Meningkatkan ketekunan berarti melakukan pengamatan secara lebih cermat dan berkesinambungan. Dengan 
cara tersebut maka kepastian data dan urutan peristiwa akan dapat direkam secara pasti dan sistematis (Sugiyono 2008). Meningkatkan ketekunan itu ibarat kita mengecek soal-soal, atau makalah yang telah dikerjakan, apakah ada yang salah atau tidak. Dengan meningkatkan ketekunan itu, maka peneliti dapat melakukan pengecekan kembali apakah data yang telah ditemukan itu salah atau tidak. Demikian juga dengan meningkatkan ketekunan maka, peneliti dapat memberikan deskripsi data yang akurat dan sistematis tentang apa yang diamati (Sugiyono 2017).

\section{c) Triangulasi}

Dalam penelitian ini menggunakan triangulasi sumber. Triangulasi sumber digunakan untuk pengecekan data tentang keabsahannya, membandingkan hasil wawancara dengan isi suatu dokumen dengan memanfaatkan berbagai sumber data informasi sebagai bahan pertimbangan. Dalam hal ini penulis membandingkan data hasil observasi dengan data hasil wawancara, dan juga membandingkan hasil wawancara dengan wawancara lainnya

\section{HASIL DAN PEMBAHASAN}

Hasil penelitian hendaknya dituliskan secara jelas dan padat. Diskusi hendaknya menguraikan arti pentingnya hasil penelitian, bukan mengulanginya. Hindari penggunaan sitasi dan diskusi yang berlebihan tentang literatur yang telah dipublikasikan.

\section{A. Analisis Praktik Sewa Menyewa Mobil dump truck Di CV Tunggal Perkasa}

Hasil dari wawancara serta observasi di atas penulis menyimpulkan bahwa Bisnis di bidang jasa persewaan mobil ini melibatkan perjanjian antara 2 (dua) orang yang saling bersepakat, yaitu pihak pemilik sewa dan pihak penyewa. Akad yang dilakukan dalam praktik sewa menyewa mobil dump truck ini dilakukan secara tertulis maupun lisan. Perjanjian tertulis yang diterapkan dalam akad rental mobil ini berupa kontrak akad yang berisi perjanjian dan sebagai tanda bukti pembayaran. Sedangkan perjanjian lisan dilakukan melalui pembicaraan antar kedua belah pihak dan pemberian kuitansi sebagai tanda bukti kesepakatan dan pelunasan sewa. Penyerahan mobil yang hendak disewa oleh pihak penyewa merupakan penyerahan yang bersifat nyata dan sebagai awal dari pelaksanaan perjanjian sewa menyewa mobil. Sedangkan pembayaran yang dimaksud biasanya merupakan akhir dari pelaksanaan perjanjian sewa menyewa mobil, atau sebagai hal yang menentukan berakhinya perjanjian sewa menyewa mobil.

Akad sewa menyewa yang dilakukan oleh kedua belah pihak ini meggunakan sebuah surat/dokumen berupa PO (Purchase Order) yaitu sebuah dokumen resmi yang dibuat oleh perusahaan (penyewa) yang berisi tentang rangkuman barang atau jasa, juga berfungsi sebagai kontrak untuk membentuk kesepakatan. Pada dasarnya penyewaan yang dilakukan di CV Tunggal Perkasa salah satunya termasuk pelayanan All In artinya harga yang dibayarkan oleh pihak penyewa kepada pihak rental sudah melingkupi biaya operasional perjalanan seperti biaya sewa mobil, jasa sopir, uang makan sopir, dan BBM (Bahan Bakar Mobil). Maka, pihak penyewa tidak perlu mengeluarkan biaya lagi terkait keperluan mobil, karena harga sewa yang telah penyewa bayarkan sudah meliputi kebutuhan perjalanan ke tempat tujuan yang telah ditentukan. Pada pelayanan sewa mobil ini, memiliki harga yang berbeda-beda pada setiap angkutan. Tergantung dengan barang bawaan/ mobil yang dibutuhkan. Serta berakhirnya akad ijarah di tempat CV Tunggal Perkasa ketika seseorang yang melakukan penyewaan tanpa sopir yaitu, mengembalikan 
mobil ke CV tunggal perkasa kemudian membayar upah ke pihak pemilik sewa. Serta kalau penyewa menyewa beserta sopir dan sudah terpenuhinya manfaat yang diakadkan sesuai massa yang telah ditentukan dan selesainya pekerjaan.

Hal ini dari data yang penulis temukan untuk akad sewa menyewa yang dilakukan CV Tunggal Perkasa dengan perusahaanperusahaan sampai saaat ini masih terikat dan kegiatan itu setiap hari masih dilakukan. Tapi pernah ada salah satu perusahaan dalam perjanjian pihak penyewa menggunakan jasa angkut mobil di CV Tunggal Perkasa selama beberapa bulan kemudian massa waktu habis tidak melanjutkan, kemudian selang dalam 2 bulan pihak penyewa/perusahaan menghubungi pihak pemilik $\mathrm{CV}$ untuk meminta mengirim beberapa unit mobil umtuk melakukan ekspedisi lagi.

\section{B. Tinjauan Ekonomi Syariah Terhadap Sewa Menyewa Mobil Dump Truck Di CV Tunggal Perkasa}

Akad Ijarah adalah akad sewa antara $m u$ 'jir dengan musta'jir atau antara musta'jir dengan ajir untuk mempertukarkan manfa'ah dan ujrah, baik manfaat barang maupun jasa. Ijarah terbagi menjadi dua macam yaitu ijarah barang dan ijarah jasa. Pihak yang terlibat dalam ijarah barang adalah pihak penyewa sebagai musta'jir dan pihak pemilik sewa sebagai mu'jir. Sedangkan pada ijarah jasa, pihak yang terlibat adalah pihak pemilik jasa yaitu sopir (ajir) dan pihak penyewa jasa yaitu pemilik rental (musta'jir). Maka, rukun ijarah pada sewa menyewa barang dan jasa berbeda. Mekanisme sewa menyewa di CV Tunggal Perkasa ditinjau dari sudut pandang ekonomi Islam disesuaikan dengan Fatwa Dewan Syariah Nasional-Majelis Ulama Indonesia NO: 112/DSN-MUI/IX/2017 sebagai berikut:

Tabel 4.2

Ketentuan terkait shigat akad ijarah

\begin{tabular}{|c|l|c|c|}
\hline \multirow{2}{*}{ No } & \multicolumn{1}{|c|}{ Urian/Ketentuan } & \multicolumn{2}{c|}{$\begin{array}{c}\text { Kesesuaian } \\
\text { syariah }\end{array}$} \\
\cline { 3 - 4 } 1 & $\begin{array}{l}\text { Ya } \\
\text { 1 }\end{array}$ & $\begin{array}{l}\text { Akad Ijarah harus } \\
\text { dinyatakan secara tegas } \\
\text { dan jelas serta } \\
\text { dimengerti oleh Mu'jir } \\
\text { /Ajir dan Musta'jir. }\end{array}$ \\
\hline \multirow{2}{*}{2} & $\begin{array}{l}\text { Akad Ijarah boleh di } \\
\text { lakukan secara lisan, } \\
\text { tertulis, isyarat, dan } \\
\text { perbuatan / tindakan, } \\
\text { serta dapat dilakukan } \\
\text { secara elektronik sesuai } \\
\text { syariah dan peraturan } \\
\text { perundang-undangan } \\
\text { yang berlaku. }\end{array}$ & $\mathrm{V}$ & \\
\hline
\end{tabular}

Mengenai ketentuan terkait shigat pada poin pertama adanya kesuaian syariah dalam sewa menyewa dump truck bahwa ketentuan dalam sewa menyewa dump truck dilakukan secara tegas dan jelas dijelaskan dari kedua belah pihak yaitu pihak $\mathrm{CV}$ dan pihak perusahaan. Pada poin kedua adanya kesesuaian syariah, dalam sewa menyewa dump truck dilakukan secara tertulis diatas surat Purchasing Order (PO) yang dibuat oleh perusahan ke pihak $\mathrm{CV}$.

Tabel 4.3

\begin{tabular}{|c|l|c|c|}
\hline \multicolumn{2}{|c|}{ Ketentuan terkait Mu'jir, Musta'jir dan Ajir } \\
\hline \multirow{2}{*}{ No } & \multicolumn{1}{|c|}{ Uraian/Ketentuan } & \multicolumn{2}{|c|}{$\begin{array}{l}\text { Uraian } \\
\text { /Ketentuan }\end{array}$} \\
\cline { 2 - 4 } 1 & $\begin{array}{l}\text { Mu'jir, musta'jir dan ajir } \\
\text { wajib cakap hukum } \\
\text { sesuai dengan syariah } \\
\text { dan peraturan } \\
\text { perundang-undangan. }\end{array}$ & $\mathrm{V}$ \\
\hline 2 & $\begin{array}{l}\text { Mu'jir wajib memiliki } \\
\text { kemampuan untuk } \\
\text { menyerahkan manfaat. }\end{array}$ & $\mathrm{V}$ & \\
\hline
\end{tabular}

EKSISBANK (Ekonomi Syariah dan Bisnis Perbankan), Volume 5, Nomor 1, Juni 2021 http://journal.sties-purwakarta.ac.id/index.php/EKSISBANK/ 


\begin{tabular}{|c|l|c|c|}
\hline 3 & $\begin{array}{l}\text { Musta'jir wajib memiliki } \\
\text { kemampuan untuk } \\
\text { membayar ujrah. }\end{array}$ & $\mathrm{V}$ & \\
\hline
\end{tabular}

Mengenai ketentuan dengan Mu'jir, Musta'jir dan Ajir. Pada poin pertama adanya ketidaksesuaian syariah dikarena pada sewa menyewa dump truck kedua belah pihak yang melakukan sewa menyewa tidak mempunyai cakap hukum dalam hukum syariah. Poin kedua adanya kesesuaian syariah karena pihak CV mempunyai wewenang untuk menyerahkan manfaat berupa dump truck kepada perusahaa. Dan poin kelima adanya kesusaian syariah dalam sewa menyewa dump truck pihak perusahaan memiliki kewajiban untuk membayar biaya sewa atas sewa menyewa dumptruck tersebut.

Tabel 4.4

Ketentuan terkait Manfaat barang

\begin{tabular}{|c|l|c|c|}
\hline \multirow{2}{*}{ No } & \multicolumn{1}{|c|}{ Uraian/Ketentuan } & \multicolumn{2}{|c|}{$\begin{array}{c}\text { Kesesuaian } \\
\text { Syariah }\end{array}$} \\
\cline { 2 - 4 } & Ya & Tidak \\
\hline & $\begin{array}{l}\text { Mahall al-manfa'aft } \\
\text { harus berupa barang } \\
\text { yang dapat } \\
\text { dimanfaatkan dan } \\
\text { manfaatnya dibenarkan } \\
\text { (tidak dilarang) secara } \\
\text { syariah (mutaqawwam). }\end{array}$ & V & \\
\hline $\begin{array}{l}\text { Mahall al-manfa'ah } \\
\text { sebagaimana dalam } \\
\text { angka 1, harus dapat di } \\
\text { serahterimakan(maqdur } \\
\text { al-taslim) pada saat akad } \\
\text { atau pada waktu yang } \\
\text { disepakati dalam akad } \\
\text { ijarah maushufah fi al- } \\
\text { dzimmah. }\end{array}$ & $\mathrm{V}$ & \\
\hline
\end{tabular}

Mengenai ketentuan terkait manfaat barang dari dua poin diatas menunjukan bahwa antara kesesuaian fatwa dengan praktik sewa menyewa mobil dump truk dilihat dari manfaat barang yang di jadikan objek, Objek akad pada ijarah barang adalah mobil yang disewakan oleh pemilik maupun orang yang ditunjuk untuk mewakilinya dalam melakukan pekerjaan mengangkut barang/ekspedisi barang kepada pihak penyewa dan jelas dapat diserahterimakan.

Tabel 4.5

Ketentuan Terkait Manfaat waktu barang

\begin{tabular}{|c|c|c|c|}
\hline \multirow[t]{2}{*}{ NO } & \multirow[t]{2}{*}{ Uraian/Ketentuan } & \multicolumn{2}{|c|}{$\begin{array}{c}\text { Kesesuaian } \\
\text { Syariah }\end{array}$} \\
\hline & & $\mathrm{Ya}$ & Tidak \\
\hline 1 & $\begin{array}{l}\text { Manfaat harus berupa } \\
\text { manfaat yang } \\
\text { dibenarkan (tidak } \\
\text { dilarang) secara syariah } \\
\text { (mutaq aww am). }\end{array}$ & V & \\
\hline 2 & $\begin{array}{l}\text { Manfaat harus jelas } \\
\text { sehingga diketahui oleh } \\
\text { Mu'jir dan } \\
\text { Musta'jir/Ajir. }\end{array}$ & V & \\
\hline 3 & $\begin{array}{l}\text { Tata cara penggunaan } \\
\text { barang sewa serta } \\
\text { jangka waktu sewa } \\
\text { harus disepakati oleh } \\
\text { Mu'jir dan Musta'jir. }\end{array}$ & & V \\
\hline 4 & $\begin{array}{l}\text { Musta'jir dalam akad } \\
\text { ijarah 'ala al-a'yan, } \\
\text { boleh menyewakan } \\
\text { kembali (al-ijarah min } \\
\text { al-bathin) kepada pihak } \\
\text { lain, kecuali tidak } \\
\text { diizinkan (dilarang) } \\
\text { oleh Mu jir. }\end{array}$ & & V \\
\hline 5 & $\begin{array}{l}\text { Musta'jir dalam akad } \\
\text { ijarah 'ala al-a'yan, tidak } \\
\text { wajib menanggung } \\
\text { risiko terhadap kerugian } \\
\text { yang timbul karena } \\
\text { pemanfaatan, kecuali } \\
\text { karena al-ta'addi, al- } \\
\text { taqshir, atau mukhal } \\
\text { afat al-syuruth. }\end{array}$ & V & \\
\hline
\end{tabular}

EKSISBANK (Ekonomi Syariah dan Bisnis Perbankan), Volume 5, Nomor 1, Juni 2021 
Mengenai Ketentuan Terkait Manfaat waktu barang. Pada poin pertama, adanya kesesuaian syariah dalam sewa menyewa dump truck adanya kejelasan objek dan manfaatnya. Pada poin kedua adanya kesesuaian syariah dalam sewa menyewa mobil dump truck sebab manfaat dari barang/mobil dump truck yang digunakan untuk melakukan kegiatan ekspedisi telah diketahui jelas oleh kedua belah pihak antara $\mathrm{cv}$ dengan perusahaan penyewa mobil dump truck. Pada poin ketiga adanya ketidak sesuaian sayariah karena dalam kegiatan akad sewa menyewa yang dilakukan oleh cv dengan perusahaan penyewa mobil dump truck ini, untuk jangka waktu sewa tidak adanya kejelasan yang diberikan oleh perusahaan atau pihak penyewa. tanpa ada ketentuan jangka waktu yang belum jelas. Poin keempat, tidak adanya kesesuaian syariah hal ini menunjukan bahwa ketentuan akad sewa menyewa tentang resiko dan kerugian objek manfaat yang dilakukan oleh musta'jir/penyewa belum sesuai dengan ketentuan syariah hal ini dibuktikan dengan perjanjian awal yang menyebutkan bahwa penyewa/perusahaan, mebutuhkan jasa sewa untuk memenuhi kebutuhan perusahaan dibidang ekspedisi ini secara all in maksudnya penyewa/musta'jir menyewa mobil dari $m u$ 'jir/pemilik sewa paket komplit beserta sopir, jadi apabila ada kerusakan mobil, kecelakaan dan resiko yang terjadi di jalan semua ditanggung oleh pemilik sewa. Akan tetapi apabila sang sopir (pihak pemilik mobil) dalam melakukan ekspedisi barang yang di bawa mengalami kerusakan yang cukup parah maka dari pihak pemilik mobil harus mengganti rugi ke perusahaan/penyewa sekian persen sesuai kesepakatan yang telah ditentukan. Disini dapat disimpulkan bahwa akad sewa menyewa yang terjadi mengenai musta'jir tidak wajib menanggung resiko terhadap kerugian yang timbul karena pemanfaatan tidak sesuai dengan ketentuan syariah. Karena akad sewa menyewa yang dilakukan di CV Tunggal Perkasa ini bukan termasuk dalam ijarah ala al-a'yan yang masuk dalam kategori properti/ kepemilikan. Poin kelima adanya kesesuian syariah terkait resiko yang ditanggu oleh musta'jir bahwasanya dalam melakukan kegitan dalam sewa menyewa ini musta'jir tidak menanggung resiko ketika ketika ada sesuatu yang terjadi pada saat menggunakan pemanfaat pada objek tersebut kecuali karenaresiko kerugian atas yang dilakukan oleh penyewa/ perusahaan dengan melanggar ketentuan yang berlaku.

Tabel 4.6

Ketentuan Terkait Ujrah

\begin{tabular}{|c|c|c|c|}
\hline \multirow[t]{2}{*}{$\mathrm{NO}$} & \multirow[t]{2}{*}{ Uraian/Ketentuan } & \multicolumn{2}{|c|}{$\begin{array}{c}\text { Kesesuaian } \\
\text { Syariah }\end{array}$} \\
\hline & & $\mathrm{Ya}$ & Tidak \\
\hline 1 & $\begin{array}{l}\text { Ujroh boleh berupa } \\
\text { uang, manfaat } \\
\text { barang,jasa, atau barang } \\
\text { yangboleh } \\
\text { dimanfaatkan menurut } \\
\text { syariah( } \text { mutaqawwam) } \\
\text { dan } \\
\text { peraturanperundang- } \\
\text { undangan yang berlaku. }\end{array}$ & V & \\
\hline 2 & $\begin{array}{l}\text { Kuantitas dan/atau } \\
\text { kualitas ujrah harus } \\
\text { jelas, baik berupa angka } \\
\text { nominal, prosentase } \\
\text { tertentu, atau rumus } \\
\text { yang disepakati } \\
\text { dandiketahui oleh para } \\
\text { pihak yang melakukan } \\
\text { akad. }\end{array}$ & V & \\
\hline 3 & $\begin{array}{l}\text { Ujrah boleh dibayar } \\
\text { secara tunai, } \\
\text { bertahap/angsuran, dan } \\
\text { tangguh berdasarkan } \\
\text { kesepakatan sesuai } \\
\text { dengan syariah dan/atau }\end{array}$ & & V \\
\hline
\end{tabular}




\begin{tabular}{|l|l|l|l|}
\hline & $\begin{array}{l}\text { peraturan perundang- } \\
\text { undangan yang berlaku. }\end{array}$ & & \\
\hline \multirow{4}{*}{4} & $\begin{array}{l}\text { Ujrah yang telah } \\
\text { disepakati boleh } \\
\text { ditinjau-ulang atas } \\
\text { manfaat yangbelum } \\
\text { diterima oleh Mustallr } \\
\text { sesuai kesepakatan. }\end{array}$ & & \\
\hline
\end{tabular}

Mengenai ketentuan akad sewa menyewa tentang ujroh yang dilakukan di CV Tunggal Perkasa pada poin pertama sudah jelas berupa uang, hal ini dibuktikan dengan pembayaran yang dilakukan oleh penyewa setelah melakukan kegitannya, juga dibuktikan ketika pihak pemilik sewa mendapatkan PO (Purchase Order) dan dijadikan invoiceuntuk mengklaim pembayaran ke perusahaan/penyewa. Poin kedua adanya kesesuaian syariah terkait kejelasan kuantitas dan kualitas ujrah, dalam hal sewa menyewa mobil dump truck bahwa ujrah atau biaya yang dikenakan kepada perusahaan dijelaskan sesuai dengan ketentuan mobil yang digunakan untuk melakukan ekspedisi sebab di CV Tunggal Perkasa ada banyak macam mobil yang disewakan. Pada poin ketiga adanya ketidak kesesuaian syariah pada akad sewa menyewa mobil dump truck ini terkait pembayaran ujrah, sebab dalam hal ini system pembayaranya tidak boleh diangsur maupun ditangguhkan. Poin keempat adanya kesesuaian syariah terkait penijauan ulang atas ujrah yang belum diterima, jadi ketika penyewa mau melakukan kegitan, pihak pemilik mempersilahkan kepada penyewa menijau ulang objek yang digunakan untuk manfaat tersebut.

Berdasarkan ketentuan-ketentuan diatas bahwa kesesuaian antara objek dalam mekanisme sewa menyewa di CV Tunggal Perkasa sebagian besar telah sesuai dan beberapa poin yang belum sesuai berdasarkan Fatwa Dewan Syariah Nasional-Majelis

\section{Ulama Indonesia NO: 112/DSN- MUI/IX/2017.}

\section{KESIMPULAN}

Setelah penulis mendeskripsikan mengenai mekanisme pelaksanaan praktik sewamenyewa mobil dump truck di CV Tunggal Perkasa sebagaimana telah dijelaskan pada bab-bab sebelumnya maka penulis menarik kesimpulan dalam skripsi ini.

Sebuah perusahaa membutuhkan jasa mobil maka antara pihak penyewa (perusahaan) dan pihak yang disewa (CV Tunggal Perkasa) melakukan sebuah kontrak perjanjian dengan syarat dan ketentuan yang sudah di tetapkan. Dan sistem sewa-menyewa yang diterapkan pada kedua belah pihak tersebut yaitu terikat secara terus menerus, dimana kontrak perjanjiannya dilakukan sekali ketika awal perjanjian. Dan untuk akad sewa-menyewa selanjutnya dilakukan dengan cara dari pihak penyewa memberi surat berupa PO (Purchase Order) atau daftar mobil yang dibutuhkan.

Berangkat dari praktik yang sudah di lakukan, maka pelaksanaan akad pada praktiknya tidak sesuai dengan ketentuanketentuan Fatwa Dewan Syariah NasionalMajelis Ulama Indonesia NO: 112/DSNMUYIX/2017. Dikarenakan ada beberapa poin yang tidak sesuai, diantara poin-poin tersebut sebagai berikut yaitu pertama terkait mu'jir dan mustajir dalam sewa manyewa rental mobil dump truck di CV. Tunggal Perkasa jika ditinjau di lapangan dalam praktinya kedua belah pihak ini belum cakap hukum sesuai dengan syariah dan peraturan perundang-undangan, kedua terkait manfaat dan waktu dalam sewa menyewa mobil dump truck ketika penyewa/perusahaan membutuh kan atau menyewa mobil dump truck dari cv untuk melakukan sebuah ekspedisi, pihak perusahaan hanya mengirim sebuah surat berupa Purches Order (PO) tanpa ada 
ketentuan jangka waktu yang belum jelas, juga tidak bisa menyewakan kembali kepada pihak ketiga berbeda dengan ketentuan fatwa, ketiga tentang ujrah dalam ketentuan fatwa ujrah boleh dibayar secara tunai, bertahap langsur, dan tangguh berdasarkan kesepakatan sesuai dengan syariah dan/atau peraturan perundang-undangan yang berlaku sedangkan dalam transaksi sewa menyewa yang dilakukan di CV. Tunggal Perkasa ini pembayaran tidak boleh secara angsur.

\section{DAFTAR PUSTAKA}

Afandi, M. Yazid. 2010. Fiqh Muamalah. Yogyakarta: Logung Pustaka.

Antonio, Muhammad Syafii. 2001. Bank Syariah: Dari Teori Ke Praktek. Jakarta: Gema Insani.

Arikunto, Suharsimi. 2013. Prosedur Penelitian Suatu Pendekatan Praktek, Cet. Ke-15. Jakarta: Rineka Cipta.

Ash-Shiddieqy, Hasbi. 2002. 2002 Mutiara Hadits. Jakarta: Bulan Bintang.

Barbara, Theresia Ocnalica. 2015. "Analisis Komparatif Antara Membeli Dan Menyewa Dump Truck PT. Global Daya Manunggal Di Sangatta." Administrasi Bisnis 3(2): 16.

Ghazaly, Abdul Rahman, Ghufron Ihsan, and Sapiudin Shidiq. 2010. Fiqh Muamalah. Jakarta: Kencana Prenada Media Group.

Handokoe, Setiadi, and Iwan B Santoso. 2018. "Optimasi Penyewaan Dump Truck Pada Proyek X Di Wilayah Jakarta Dengan Metode Linear Programming." JMTS: Jurnal Mitra Teknik Sipil 1(1): 72. https://journal.untar.ac.id/index.php/jmts /article/view/2244.

Hasan, M. Ali. 2003. Berbagai Macam Transaksi Dalam Islam (Fiqh Muamalat). Jakarta: Raja Grafindo Persada.
Hendryadi, Suryani. 2015. Metode Riset Kuantitatif Teori Dan Aplikasi Pada Penelitian Bidang Manajemen Dan Ekonomi Islam. Jakarta: Prenadamedia Group.

Janwari, Yadi. 2015. Fikih Lembaga Keuangan Syari'ah. Bandung: Rosda Karya.

Mahmud. 2011. Metode Penelitian Pendidikan. Bandung: CV Pustaka Setia.

Marcell, Geraldy, and Hendrik Sulistio. 2021. "Perbandingan Investasi Dengan Sewa Alat Berat Pada Proyek Pembangunan Hotel Ibis Raden Saleh Jakarta." JMTS: Jurnal Mitra Teknik Sipil 4(1): 313. https://journal.untar.ac.id/index.php/jmts /article/view/10480.

Moleong, Lexy J. 2017. Metodologi Penelitian Kualitatif. Bandung: Remaja Rosdakarya.

Nurjaman, Maman. 2019. "Praktik Sewa Menyewa Rental Mobil Dump Truck."

Sariningsih, Nasih, Saepul Bahri, and Ayi Nurbaeti. 2020. "Pengaruh Pelayanan Islami Terhadap Kepuasan Konsumen Di 212 Mart Purwakarta." EKSISBANK (Ekonomi Syariah Dan Bisnis Perbankan)2 4(2): 140-56.

Subekti, R., and R. Tjitrosudibio. 2014. Kitab Undang-Undang Hukum Perdat. Jakarta: Balai pustaka.

Sugiyono. 2008. Metode Penelitian Kuantitatif Kualitatif. Bandung: Alfabeta. . 2017. Metode Penelitian Kuantitatif, Kualitatif, Dan R\&D. Bandung: Alfabeta.

Suhendi, Hendi. 2014. Fiqh Muamalah. Cetakan 9. Jakarta: Raja Grafindo Persada.

2016. Fiqh Muamalah. Jakarta: Raja Grafindo Persada. 
Sukasari, Pesantren Persis. Bulughul Maram Min Adillatil Ahkaam.

Syafei, Rachmat. 2006. Fiqih Muamalah. Bandung: Pustaka Setia.

. 2011. FIQIH Muamalah. Bandung: Pustaka Setia.

Tanuwijaya, Handoko. 2012. Bisnis Rental Untung Miliaran. Yogyakarta: Crop Circle Group.

Zuhaili, Wahbah. 2010. Al-Fiqhu Asy-Syafi"i Al-Muyassar, Diterjemahkan Muhammad Afifi, Abdul Hafiz (Fiqih Imam Syafi"i 2). Jakarta: Almahira. 